\title{
Stalking, mental disease, imputability: Thoughts on 20 cases
}

\author{
Francesca Manunza, ${ }^{1}$ Giampaolo Pintor ${ }^{2}$ \\ ${ }^{1}$ Medical Director, Psychiatrist ATS Sardinia, Psychotherapist, Criminologist, Forensic Psychopathologist; ${ }^{2}$ Psychiatrist, \\ Founding Member and Member of the Board of Directors of the Italian Society of Forensic Psychiatry, Italy
}

\begin{abstract}
Stalking is the product of an interaction between context (including the dyadic relationship between stalker and victim) and individual factors such as psychopathology. Those who have stalking behaviour are often affected by mental disorders that may have a direct or indirect role in committing stalking. Literature reports that stalkers of former partners represent the widest sub-category of stalkers. A 2003 study indicates an average percentage of $49 \%$ stalkers of former partners reported in 40 , showing a significant diversity of stalking behaviours with a faster wearing out rate. Several studies indicate a greater prevalence of psychosis among those who persecute strangers or acquaintances compared to stalkers of former partners $(25 \%$ vs $11 \%)$. Some studies, besides the present survey, indicate a high prevalence of not otherwise specified Personality Disorders in stalkers, suggesting that stalking behaviour may be associated with several personality traits of various disorders. This study aims at finding empirical evidence to the data reported by the relevant scientific literature. We examined the expert surveys of 20 stalkers subjected to psychiatric-forensic evaluation for the crime of stalking (article 612/bis) in the years 2016/2017, drawn up by the Forensic Psychiatry Service in Cagliari. Through a specific grid, which allowed to guarantee anonymity and that stalkers could not be identified, they analyzed some demographic variables (age, sex, marital status, educational qualification), stalkers' diagnoses, victims' typology, types of stalking performed, paying a particular attention to violence manifestations, stalking duration and some psychiatric-forensic data. Our survey has highlighted that 19 stalkers $(95 \%)$ are males, do not have a stable affective relationship and had to refer at least once to the Mental Health Service; (70\%) of stalkers are unemployed or retired. From the psychiatric-forensic point of view, 14 stalkers (70\%) are partially mind defective, $5(25 \%)$ are totally mind defective, 1 has been recognized as mentally incompetent; $13(65 \%)$ are socially dangerous. Furthermore, $45 \%$ of stalkers are affected by not otherswise specified (NOS) Personality Disorder. The prevalent diagnoses (Axis I) detected are: 8 stalkers (40\%), are affected by Substance Use Disorder, 6 (30\%), Bipolar and related disorders, 5 (25\%) Spectrum Disorders of Schizophrenia and other Psychotic Disorders; $45 \%$ of victims of stalking are former partners. Due to the high possibility that stalkers develop a violent behaviour, present in half of the stalkers of former partners, and the chance of crime recidivism, in particular among stalkers affected by Personality Disorder, the Service of Forensic Psychiatry in Cagliari, in agreement with the Court, is drawing up guidelines that provide for the establishment of proper services where to follow the stalkers in order to limit recidivism of this crime.
\end{abstract}

\section{RIASSUNTO}

Lo stalking è il prodotto di un'interazione tra contesto (compresa la relazione diadica tra stalker e vittima) e fattori individuali come la psicopatologia. Coloro che assumono comportamenti di stalking sono spesso affetti da disturbi mentali che possono avere un ruolo diretto o indiretto nel perpretare il comportamento. In letteratura si rileva che gli stalker d'ex-partner rappresentino la sottocategoria più ampia di stalker; uno studio del 2003 riporta una percentuale media del (49\%) di stalker d'ex-partner su 40 studi, essi mostrano una maggiore diversità di comportamenti di stalking con un tasso di logoramento più veloce. Vari studi indicano una maggior prevalenza di psicosi tra coloro che perseguitano estranei o conoscenti rispetto agli stalker d'ex-partner (25\% vs 11\%). Alcuni studi, oltre il presente, indicano una prevalenza alta di Disturbi di Personalità Nas negli stalker, suggerendo che il comportamento di stalking possa essere associato ad una combinazione di tratti di personalità di diversi disturbi. Il presente contributo si propone di trovare dei riscontri empirici ai dati suggeriti dalla letteratura scientifica di riferimento. Abbiamo esaminato il fascicolo peritale di 20 stalker sottoposti a valutazione psichiatrico-forense per il reato di stalking (art. 612/bis) negli anni 2016/2017, dal Servizio di Psichiatria Forense di Cagliari. Tramite un'apposita griglia, che ha permesso di garantire l'anonimato e la non riconoscibilità degli autori di reato, sono state analizzate alcune variabili demografiche (età, sesso, stato civile, scolarità), le diagnosi degli stalker, la tipologia della vittima oggetto di stalking, le forme di stalking esercitate, con particolare attenzione alle manifestazioni di violenza, la durata dello stalking e alcuni dati di tipo psichiatrico-forense. Il (95\%) degli stalker esaminati è di sesso maschile n.=19 (M) (95\%), non ha una relazione affettiva stabile, ha avuto almeno un accesso al Dipartimento di Salute Mentale, il (70\%) degli stalker è disoccupato o pensionato. Dal punto di vista psichiatrico forense $\mathrm{n} .=14$ stalker ( $70 \%)$ sono affetti da vizio parziale di mente, $n .=5(25 \%)$ da vizio totale di mente, $n .=1$ stalker è stato riconosciuto capace d'intendere e volere; $n .=13(65 \%)$ erano pericolosi socialmente. Il (45\%) degli stalker sono affetti da Disturbo di Personalità Nas. Le diagnosi prevalenti (Asse I) sono: D. da Addiction in n. $=8$ stalker (40\%), Disturbi Bipolari e disturbi correlati n. $=6$ stalker (30\%), Disturbi dello Spettro della Schizofrenia e altri disturbi Psicotici, in n. $=5$ casi $(25 \%)$. Il (45\%) delle vittime di stalking sono ex-partner. Vista l'alta possibilità di comportamenti violenti nello stalking, presenti nella metà dei casi di stalking di ex-partner, e l'alta possibilità di reiterazione del reato in particolare tra gli stalker affetti da Disturbo di Personalità, il Servizio di Psichiatria Forense di Cagliari in accordo con gli Uffici Giudiziari, sta lavorando a delle linee guida che prevedono la creazione di centri che si occupino della cura dello stalker al fine di contenere la recidiva di reato.

\section{RESUME}

El acoso es el producto de una dinámica entre el contexto (incluyendo la relación dual entre el acosador y la víctima) y elementos individuales como la psicopatología. Los que practican actividades de acoso son, a menudo, afectados por disturbios mentales que pueden directa o indirectamente llevar un papel en cometer dicho comportamiento. En bibliografía se evidencia que los acosadores "ex parejas" 
representan la subcategoría mas amplia de acosadores; un estudio en 2003 reporta un porcentaje promedio del $49 \%$ de acosadores "ex parejas" sobre cuarenta estudios. Estos casos evidencian una mayor diversidad de práctica de acoso con una modalidad de agotamiento más rápida. Diferentes estudios indican una mayor prioridad de psicosis entre aquellos que acosan a extraños o a conocidos con respecto a aquellos acosadores en contra de ex parejas: $25 \%$ versus $11 \%$. Unos estudios, a parte del presente, indican una alta mayoría de Disturbios de Personalidad NAS entre los acosadores, sugiriendo que el comportamiento de acoso puede ser asociado a una combinación entre diferentes disturbios de la personalidad. Esta aportación se propone encontrar evidencias prácticas a los datos sugeridos por la bibliografía científica disponible. Hemos examinado el expediente calificado de veinte acosadores evaluados bajo el punto de vista psiquiátrico y forense por el crimen de acoso (art. 612/bis) en los años 2016/2017, por el Servicio de Psiquiatría Forense de Cagliari. A través de un proceso especialmente dedicado que permitió garantizar el anonimato y la imposibilidad de descubrir los actores del crimen, han sido analizadas algunas variantes demográficas (edad, sexo, estado civil, nivel de escolarización), los diagnósticos de los acosadores, la tipología de las víctimas de acoso, las formas de acoso ejecutadas, con particular énfasis en las manifestaciones de violencia, el tiempo de demora del acoso y unos datos a nivel psiquiátrico y forense. El 95\% de los acosadores evaluados pertenece al sexo masculino (19 hombres ), no tiene una relación afectiva estable, tuvo por lo menos un contacto con el Departamento de Salud Mental; el 70\% de los acosadores no tiene empleo o es jubilado. Desde un punto de vista psiquiátrico forense 14 acosadores (70\%) padecen de vicios parcial de mente, 5 (25\%) padecen de vicio total de mente, 1 acosador fue evaluado capaz de entender y querer; 13 eran peligrosos socialmente. El 45\% de los acosadores padecen de disturbio de personalidad no especificado. Los diagnósticos mayoritarios son: Disturbios da Adicción: 8 acosadores (40\%), disturbios Bipolar y disturbios consiguientes: 6 acosadores (30\%), disturbios con relación a la esquizofrenia y además otros disturbios psicóticos: 5 (25\%). Il $45 \%$ de las víctimas de acoso son ex parejas. Debido a la elevada posibilidad de actos violentos que conlleva el acoso, relevados en la mitad de los casos de acoso por ex parejas y la elevada posibilidad de repeticiones del crimen, particularmente entre los acosadores con disturbios de personalidad, el Servicio de Psiquiatría Forense de Cagliari junto con las Oficinas Judiciales, está desarrollando unos lineamientos generales con la finalidad de la creación de unidades aptas para la gestión del acoso al fin de al fine de controlar la reincidencia del crimen.

\section{Introduction}

Stalking is a widespread social phenomenon. Statistical surveys indicate that female population is involved in a percentage that varies from 8 to 18\% (Buzzi et al., 2014 from De Fazio et al. 2007).

Although stalking has to be considered a "neutral sex" behaviour, not identifiable with only one of the sexual identities (Pomilla et al., 2012, page 47), epidemiological studies show that stalkers are predominantly males and their victims are mainly females. European surveys highlight an absolute prevalence of male stalkers (85.5\% vs 14.5\%) (Catanesi, 2013 from Dressing 2005). A review of literature on stalking carried out by Meloy (1997), indicated that $72 \%$ of stalkers are males, while a meta-analysis performed by Spitzberg (2002) on 47 studies showed an average of $79 \%$ male stalkers (Sheridan, 2003 from Meloy 1997 and Spitzberg 2002).

Regarding female stalkers, rates vary according to the sample examined: from 1 out of 10 to 1 out of 4 stalkers (Ostermeyer et al., 2016 by Friedman 2015). Lower percentages of female stalkers (12$13 \%$ ) are found in surveys on the general population, while higher percentages (21-33\%) in selected samples (Catanesi, 2013).

From the analysis of literature on female stalking, the emerging profile is that of a young-adult (average age 37 years), heterosexual, with high educational qualification (high school diploma or degree), single, separated or divorced, without children. Relevant is the number of past convictions, even if the percentage is lower than that of men (Meloy and Boyd, 2003).

Besides the above mentioned socio-demographic characteristics of female stalkers, in the study conducted by Meloy and Boyd (2003) on 82 female stalkers who performed harassments in the United States, Australia and Canada, the following data have been reported: $1 / 3$ of the stalkers were mothers, almost half $(49 \%)$ of them had a psychotic disorder at the time of stalking (very common the Delusional Disorder), also frequent personality disorders, especially Borderline Personality Disorders (12\%), followed by the Narcissistic Disorder (4\%), Dependency Disorder (4\%), NOS (2\%) and Obsessive-Compulsive Personality Disorder (1\%) (Alfarano et al., 2012 from Meloy and Boyd, 2003, p. 26). Additionally, 1/3 of them had to resort to psychiatric services and 1/4 had used drugs or substances (alcohol, cannabis, amphetamines), in the period in which they were stalking. However, psychosis due to drug intoxication was less frequent in female stalkers; $1 / 3$ of the stalkers had to resort at least once to a Mental Health Service, many of them (45\%) had suffered sexual abuse 30\% physical abuse and 8\% emotional trauma (Catanesi, 2013; Alfarano et al., 2012; Gargiullo, p. 22-23 from Meloy and Boyd 2003).

The characteristics of male stalkers can be summarized as follows: man, in the fourth decade of life, unemployed or temporary employed, single or divorced with a psychiatric and/or substance abuse history (Sheridan, 2003 from Meloy 1999). However, literature reports conflicting data, e.g. Kordvani (2000) found that $71 \%$ of 100 Iranian stalkers were aged between 17 and 22 years (Sheridan, 2003 from Kordvani 2000).

Motivations behind harassments are often similar in both sexes; however, it is more likely that female stalking depends on the need to establish a couple relationship, while male stalkers are more likely to try not to give up a couple relationship (Ostermeyer et al., 2016 from West 2008 and Meloy 2013).

Regarding the choice of the victim, most men adopt persecutory behaviours only towards female victims, while almost all women under study can persecute both women and men. Women are more likely to engage in stalking individuals of the same sex than men (Ostermeyer et al., 2016). In addition, female stalkers tend to persecute victims they already know and, more frequently than men, stalk people they have had a relationship with in the professional field (Pomilla et al., 2012; Ostermeyer et al., 2016).

Female stalkers have a tendency towards threats and violence similar to that of male stalkers (Purcell et al., 2001); they use more persecutory modes than men, no less effective and dangerous than those adopted by men (West and Friedman, 2008). In particular, they are more likely to perform harassment in writing (e-mails or letters) or through telephone calls. There are fewer chances that female threats will turn into physical assaults (Ostermeyer et al., 2016). The possibility of physical aggression, as it happens also in male stalkers, increases in the case of previous intimate relationship with the victim (Alfarano et al., 2012; Ostermeyer et al., 2016). The risk of violence increases more if female stalkers use drugs and threaten their victim. The less dangerous female stalkers are those of 
Hollywood celebrities (Ostermeyer et al., 2016). No particular differences have been highlighted on duration, perseverance and intrusiveness that men and women show in the stalking behaviour; no differences have been detected in the potential damages caused by male and female stalkers (Alfarano et al., 2012).

Shifting our attention to stalking perpetrated by young people, researches indicate that, compared to that performed by adults, harassments are characterized by the use of direct, intense, openly threatening forms; high rates of physical aggression, episodes of physical violence and higher levels of threats have been reported. A greater prevalence of young female stalkers compared to adults has been reported (Ostermeyer et al., 2016; Purcell et al., 2009). Even in juvenile stalking, female stalkers do not differ from males in persistence or pushiness of an unwanted behaviour. They have a higher tendency to recruit third parties with the purpose of harassing the victim. Adolescents are more likely than adults to manifest stalking behaviours in the context of a group rather than individually. As for the motivations behind juvenile stalking, the most frequent in males are: refusal, search for intimacy and sexual predation, while in females bullying and revenge (Ostermeyer et al., 2016 by Purcell et al., 2009). A research carried out by McCann highlights that sexual interest is the primary motivation behind juvenile stalking (Ostermeyer et al., 2016 by McCann).

\section{Stalking and psychopathology}

Stalking is not necessarily the manifestation of a psychopathological disorder. In some cases, however, persecutory behaviours can fall in the symptomatology of an identifiable psychic disorder (Berti et al., 2005) that may have a direct or indirect role in stalking behaviour. According to some authors (Galeazzi and Curci, 2001), only $10 \%$ of the stalkers might have a psychopathological disorder that can be classified as a diagnosis in Axis I and Axis II. A brief review of literature, reported in Pomilla et al. (2012) on the presence of psychiatric disorders in stalkers, can be summarized as follows: 1) Schizophrenia: 44\% (Mullen et al., 2000); 2) Bipolar Disorder: 1.4 - 6\% (Meloy et al., 2001); 3) Substance Abuse and Addiction: 25-67\% (Mullen, 1999); Personality Disorders: 19-85\% (Mullen, 1999; Meloy, 1999).

Meloy (1999) noted that most stalkers have both diagnoses in Axis I and II. The most common diagnoses of Axis I, in descending order of frequency, are Substance Abuse or Addiction, Mood disorders, and Schizophrenia. On axis II, stalkers are more likely to be diagnosed with Personality Disorders of cluster B (narcissistic, histrionic, antisocial, borderline)

Examining the diagnoses most frequently detected according to the type of stalker (Mullen's classification, 2002), literature reports that: stalkers of former partners are often affected by a psychiatric disorder; the presence of psychopathology is associated with more persistent and recurrent stalking behaviours (McEwan and Strand, 2013). Stalkers of former partners are less likely to be psychotic than stalkers harassing acquaintances or strangers (Farnham et al., 2000), while they are more likely to be diagnosed with substance abuse and antisocial and narcissistic personality disorders (Sheridan et al., 2003 from Farnham et al. 2000 and Coleman 2000).

Axis I disorders are significantly more common in stalkers who harass acquaintances and strangers than stalkers of former partners (71 vs 48\%). The most frequently Axis I disturbances detected in stalkers (towards strangers) are psychotic disorders and paraphilias (29 vs 9\%) (McEwan and Strand, 2013).

The greater prevalence of diagnoses of psychosis among stalkers who persecute strangers had already been highlighted in early studies on stalking (Kienlen et al., 1997) and later confirmed by Mohandie and colleagues (2006) (in McEwan and Strand, 2013) in which, in over 1,000 cases, $25 \%$ of stalkers towards strangers and acquaintances, compared to $11 \%$ of former partners, presented psychosis. Studies on groups of victims in the professional field report psychosis rates between 25 and 45\% (McEwan and Strand, 2013 by Purcell et al. 2005; McIvor et al., 2008; Abrams and Robinson, 2011; Morgane Kavanaugh, 2011), while studies on stalkers towards public figures, report rates of above $80 \%$ (McEwan and Strand, 2013 from James et al., 2009).

The other type of psychopathology relevant to stalking is the Personality Disorder, present in $30-50 \%$ of stalkers in the clinical/forensic samples, in many studies accounting for about $50 \%$ of the samples examined (Mullen et al., 1999; McEwan and Strand, 2013 from Rosenfeld and Harmon 2002; Whyte, 2008; Morrison, 2008). This type of diagnosis was significantly associated with recurrent and relapsing stalking (McEwan and Strand, 2013; Rosenfeld, 2003). Cluster B narcissistic, antisocial and borderline disorders are the most common (McEwan and Strand, 2013 from Meloy 2007; Sansone and Sansone, 2010). No significant differences are reported regarding the prevalence of Personality Disorder diagnoses in stalkers who harass strangers compared to stalkers who persecute former partners. In stalkers of former partners and acquaintances, several studies have reported a predominance of cluster B disorders, while in stalkers towards strangers a wider range of personality traits (McEwan and Strand, 2013). Some studies, beyond the present survey, indicate a great prevalence of NOS Personality Disorders in stalkers, suggesting that stalking behaviour may be associated with a combination of personality traits of different disorders (McEwan et al., 2013; Rosenfeld, 2003).

Regarding gender differences in terms of psychiatric diagnosis, some studies highlight a high incidence of mental illness among female stalkers, a close relationship between psychiatric diagnosis and stalking, a role of mental pathology in determining tormenting harassment that, according to some authors, is more evident in women than in men (Catanesi et al., 2013).

The most frequent correlation between female stalkers and erotomania delirium is known; several studies estimate to be more frequent in females, a condition that would increase the risk of violence, representing a specific risk factor of violent behaviour (Kelly, 2017). Kraepelin suggested that erotomania illusions may serve as compensation for delusions of life (Kelly, 2017 from Kraepelin and Robertson 1921) and that they may have a relationship with unfulfilled narcissistic, heterosexual or homosexual impulses (Kelly, 2017). Traditionally, erotomania is classified as primary or secondary (Kelly, 2005): secondary erotomania may coexist with other psychiatric disorders, such as schizophrenia, bipolar affective disorder, Fregoli syndrome, Capgras syndrome, folie à deux and a multitude of other conditions (Kelly, 2017 from Kennedy et al. 2000).

Violent women more frequently are affected by Personality Disorders (in particular in cluster B, defined also as "melodramatic") and Affective Disorders (Strand S. et al., 2011).

The research of Purcell, Pathè and Mullen, which lasted 8 years (1993-2000), conducted on a sample of 190 stalkers (40 women and 150 men), highlighted that $45 \%$ of women presented Axis I disorder, in particular Erotomania Delusional Disorder (30\%). Other recurrent diagnoses reported in the study were: Schizophrenic Disorder (5\%); Bipolar Disorder (5\%); Depressive Disorder (5\%). The authors also reported a high the presence of Personality Disorders diagnosed in 50\% of female stalkers: one Borderline Disorder in $15 \%$ of cases; one Addiction Disorder (15\%), one Narcissistic Disorder (7.5\%). The remaining cases 
(12.5\%) had a not otherwise specified personality disorder. Substance Abuse Disorder was present in $7.5 \%$ of female stalkers, a percentage lower than in males (28\%) (Catanesi et al., 2013; Alfarano et al., 2012).

Despite the fact that those who engage in stalking are often affected by mental disorders, in some cases harassments are perpetrated even during good clinical compensation. In a study carried out by Catanesi and colleagues in 2013 on the coexistence and independence between mental illness and stalking, the authors report a clinical case of a female stalker affected by Bipolar Disorder with psychotic symptoms. They highlighted how the harassment was carried out by the stalker, both in the phase of maniac decompensation with psychotic symptoms (this is why the forensic psychiatrist considered her only partially chargeable), but also in the stage of clinical compensation, that is when the patient had returned to work and the harassment had continued; therefore, she was recognized chargeable for having perpetrated again the crime because stalking was explained only by psychological and existential reasons.

\section{Aim of the research}

The present survey aims at finding empirical evidence to the results reported in the relevant scientific literature, highlighting demographic characteristics, behavioural patterns, psychopathological and diagnostic data, which are more frequently associated with stalking, making a correlation with what has already been highlighted in the studies published in literature and what has been detected in the tormenting harassers considered in our sample.

We have carried out a descriptive analysis of a sample of 20 stalkers, who have been assessed by the Forensic Psychiatry Service of Cagliari in the years 2016/2017. This Service, established by the Social-Health Service of Cagliari in 2001, has a key role in the territorial forensic psychiatry that, following the agreement stipulated with the Court of Cagliari, operates on the Social-Health Service territory. It is a unique service for specificity and competences that, in addition to the usual psychiatric-forensic investigations (advice, expertise) required by the Court, carries out its activity with outstanding therapeutic, psychosocial and rehabilitation capability.

\section{Materials and Methods}

The data were extrapolated by analysing the psychiatric examinations of 20 subjects who had undergone psychiatric-forensic evaluation by the Cagliari Forensic Psychiatry Service for the crime of stalking (article 612/bis), in the years 2016/2017. Such reports were analyzed through a special grid that allowed to guarantee anonymity and avoid that perpetrators could be recognized. Some demographic variables have been taken into consideration (age, sex, marital status, educational qualification) and the stalkers' analyzed according to DSM IV-TR in Axis I and in Axis II), as well as typology of the victim of stalking, stalking modes perpetrated, paying particular attention to the manifestations of violence, duration of stalking and some psychiatric-forensic data. Furthermore, the number of stalkers considered imputable and the number of recognized stalkers affected by mental disorders, partial or total, as well as their and social dangerousness, were taken in due consideration.

\section{Results}

\section{Socio-demographic data}

The socio-demographic characteristics of our sample of 20 stalkers are summarized as follows: perpetrators are almost exclusively males (19 cases: 95\%), compared to only 1 case of female stalker $(5 \%)$. The average age most represented in the sample ranges from 41 and 52 years $(50 \%$ of the stalkers under study), followed by the two age groups equally represented, one between 22 and 30 years ( 4 cases; 20\%), and the other between 53 and 65 years ( 4 cases; $20 \%$ ); only 2 stalkers (10\%) were aged 66 and 77 years. Considering the whole sample, the average age recorded has been 48 years; excluding the two cases of elderly stalkers, the average age of the remaining 18 stalkers was 44 years. As for the marital status, the following are our results: out of all the subjects examined, 11 (55\%) were unmarried, 4 (20\%) separated, 2 $(10 \%)$ divorced, (10\%) widower, 1 married (5\%). Regarding the stalkers' educational qualification: 7 (35\%) had middle school diploma, 5 (25\%) high school diploma, $2(10 \%)$ primary school, 1 $(5 \%)$, had attended only the first primary school, 3 (15\%) had a university degree. For 2 cases it has not been possible to establish the educational qualification, as not reported in the expert surveys. Our study has highlighted that $19(95 \%)$ of stalkers had a history of at least one access to the Mental Health Services (Csm/Serd), 10 $(50 \%)$, had at least one prior psychiatric hospitalization, most cases had repeated hospitalizations, for only one stalker a suicide attempt has been reported. In the whole sample, 19 out of the $20(95 \%)$ examined stalkers, had previously been under psychiatric drug therapies; in at least 6 cases there was evidence that psychiatric therapy had not been taken during the period of stalking. As for the working activity, a high number of the subjects under study ( 8 cases: $40 \%$ ) were retired, out of the remaining sample a half ( 6 cases: $30 \%$ ) was employed and the other half (6 cases: $30 \%$ ) was unemployed.

\section{Psychiatric-forensic data}

From a forensic-psychiatric point of view, only 1 stalker has been judged as mentally competent (he had been diagnosed a NOS Personality Disorder with prevalent borderline, narcissistic and immature traits), 19 stalkers (95\%) were affected by mental disorders; out of these, 14 (70\%) by partial mental disorder, and 5 $(25 \%)$ by total mental disorder (Figure 1). Regarding the social dangerousness, 13 stalkers $(65 \%)$ have been recognized as socially dangerous, 7 (35\%) have not been recognized as socially dangerous, since most of them had already undertaken a therapeutic treatment in agreement with the Mental Health Services. All the examined stalkers in our sample were judged capable of consciously participating in the study.

\section{Diagnosis (DSM IV-TR and DSM-5)}

We subsequently analyzed the stalkers' diagnoses detected by the experts, dividing them into Axis I Diagnosis and Axis II Diagnosis (DSM IV-TR), and then evaluated the diagnoses also according to DSM-5. Axis I diagnosis have been the most frequent, even in co-morbidity with Axis II disorder. Considering the diagnosis according to DSM IV-TR the most frequently detected pathology in Axis I has been Substance Use Disorder, present in 8 stalkers ( $40 \%$ of the sample), in co-morbidity also with other Axis I or Axis II pathologies; in particular, the most frequent comorbidity has been with Mood Disorder. Mood Disorders diagnosed in 6 stalkers (30\% of the sample) have been (Cyclothymic Disorder, Major Depression, NOS Mood Disorders, and in 3 cases Bipolar Disorder); in addition to the two diagnoses of Adaptation Disorder present in $10 \%$ of the sample, 8 cases represent $40 \%$ of the sample, 
in the same percentage of Substance Use Disorder (according to DSM IV-TR). Conversely, on the basis of the classification of DSM5 , they are present only in 6 cases, considering Adaptation Disorders among the disorders related to traumatic and stressful events. In the third place we report Psychotic Disorders present in 5 stalkers of which $3(15 \%)$ cases of NOS Psychosis and 2 of Schizophrenia and Affective Psychoses which, altogether, represent $25 \%$ of the diagnoses examined in our sample. Only 1 stalker was affected by Anxiety Disorder: Obsessive-compulsive disorder (OCD) and related disorders in co-morbidity with Substance Use Disorder and Personality Pathological Traits. The elderly stalker in the sample is affected by a Cognitive Deterioration: Dementia with Psychosis.

Examining the diagnoses according to DSM-5, we have registered in the first place the diagnosis of Substance Use Disorders and Substance Addiction Disorders present in 8 stalkers $(40 \%$ of the sample), of which 4 cases with Alcohol Use Disorder and the other 4 with Substance Use Disorder (cocaine and cannabis). In the second place we have noted Bipolar Disorders and related disorders ( $30 \%$ of the sample), of which 3 cases were affected by Bipolar I Disorder, 1 case by Bipolar Disorder with other specification, 1 by Cyclothymic Disorder, and 1 by Major Depressive Disorder. In the third place the spectrum of Schizophrenia and other psychotic disorders have been reported in 5 cases $(25 \%)$ of the sample, including 2 diagnoses of Schizophrenia and Affective Psychoses. Adaptation Disorders represent $10 \%$ of the sample (Disorders related to traumatic and stressful events), considered separately from Mood Disorders, compared to DSM IV-TR. One case (5\%) had a diagnosis of OCD, in co-morbidity with Substance Use Disorder and pathological personality traits, and $1(5 \%)$ of Neurocognitive Disorder with Psychosis: he was the oldest stalker of the sample. Neurodevelopmental Disorders were detected in $15 \%$ of the subjects, and Personality Disorders in $45 \%$. Examining the personality traits present in the individuals under study, the prevalent ones are: borderline personality traits, in association or not with other pathological traits of personality, more frequently with immature and histrionic personality traits or with paranoid personality traits.

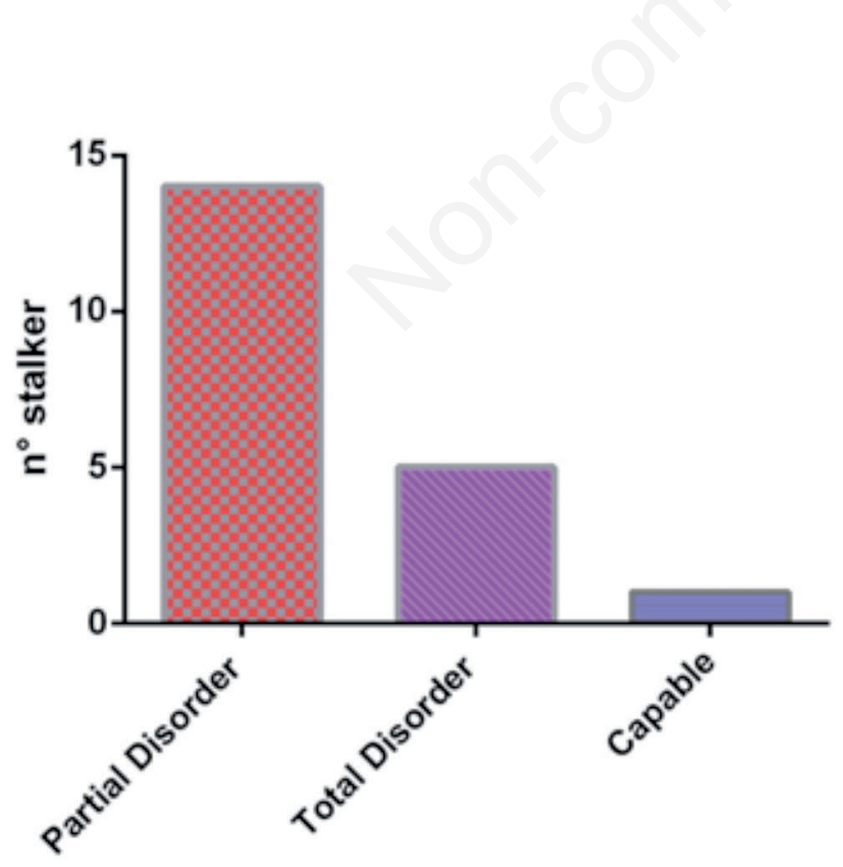

14 Partial Disorder (70\%), 5 Total Disorder (25\%), 1 Capable (5\%).

Figure 1. Mental competence.
Beyond the classification system used, from a forensicpsychiatric point of view, we have to highlight that $(95 \%)$ of the subjects had not a single diagnosis, but an interaction of several psychopathological factors that, analyzed altogether, determine a certain behaviour and, in relation to the offense, were so relevant to be considered mental diseases, such as to reduce or exclude mental competence.

\section{Stalking}

Regarding the duration of stalking behaviour, in 7 cases (35\%) was less than 6 months, in $5(25 \%) 3$ years, in $3(15 \%) 2$ years, in 2 cases (10\%) 6 years, and in other 2 cases (10\%) 1 year. Regarding the stalking modes used, we have divided the behaviours that generally fall in this phenomenon into three categories of actions: 1) following the victims (frequenting their workplaces and home, creating occasions of meeting, keeping them under surveillance; 2) communications (through phone, letters, notes, graffiti, gifts, email or internet, cyberstalking: 3 ) assaulting or exercising violence (threats, harassment, violence, directed to the victim or to persons close to the same, damage to property, false accusations, physical and sexual violence). We have considered murder separately from other types of violence.

In our sample, in 9 cases (45\%), stalking has been intense and involved implementation of all the actions reported above; 15 cases (75\%) of the sample have done acts of violence, in 1 case the victim was murdered. Numerous physical attacks, beatings, personal injuries on the victim have been reported; in 1 case the victim was stabbed. Damage of the victim's material objects has been frequently reported. In 2 cases (10\%) cyberstalking was used as a persecutory mode. Finally, as regards the victims of stalking, in 9 cases $(45 \%)$ the harassed person is a former spouse or former partner, in 4 cases $(20 \%)$ an acquaintance, in 3 cases $(15 \%)$ unknown subjects; in $10 \%$ of cases members of the stalker's family, in $10 \%$ of cases victims were numerous.

\section{Discussion}

The results of the present study are in line with what reported in literature on stalking, and allow to reflect on some aspects related to this phenomenon. Almost all the stalkers considered in our sample, with the exception of one female, are males and adults, thus confirming a prevalence of male sex, as reported in other studies.

As for the socio-demographic characteristics of the only female stalker of our sample, she is slightly older (49 years) than the average female stalkers detected from the analysis of the literature on female stalking. She has a diagnosis of Psychotic Disorder (Schizophrenia and Affective Psychoses), in line with what reported in some studies (Meloy and Boyd, 2003) and stalked some female acquaintances. In this regard, literature reports that women are more likely to perpetrate stalking against members of the same sex than men (Ostermeyer et al., 2016). The average age of male stalkers reported in our sample is between 44 and 48 years, higher than the average age found in literature. Other data of socio-demographic interest are the marital status: 19 stalkers $(95 \%)$ of our sample are in 55\% of cases unmarried, $6(30 \%)$ are divorced/separated, $2(10 \%)$ are widowers, while only $1(5 \%)$ is married. Mullen et al. (1999) observed that more than half of their sample, consisting of 145 stalkers, had never had a long-term relationship and that $30 \%$ of the cases were divorced or separated (Sheridan, 2003 from Mullen et al. 1999). In our sample, 19 cases $(95 \%)$ had to resort at least once to the Mental Health Services, 14 cases $(70 \%)$ did not have a safe working situation, were unemployed or retired. These characteristics 
perfectly fit into the "modal Stalker". The most frequent diagnoses detected in our stalker sample were: Substance Abuse Disorder in 8 cases $(40 \%)$, Personality Disorders in 9 cases $(45 \%)$, Mood Disorders in 6/8 cases, 6 cases (30\%) according to DSM-5, 8 cases (40\%) according to DSM-IV-TR, Psychoses in 5 cases, (25\%); the most frequent co-morbidity is between Axis I disorder and Axis II disorder. In our sample the diagnosis of NOS Personality Disorder is present in $45 \%$ of the sample. On the basis of the personality traits present in the subjects examined, the prevailing ones are: borderline personality traits, in association or not with other pathological personality traits, more frequently with immature and histrionic personality traits or paranoid personality traits.

In the sample we examined, the presence of pathological personality traits is associated with repeated and persistent stalking (in line with what is reported in literature), despite repeated legal proceedings that worsen with the reiteration of the crime. From the psychiatric-forensic point of view, it has to be highlighted that $95 \%$ of the cases do not report a single diagnosis (in 5\% of the sample there is only one diagnosis of Severe Schizofrenia and Affective Psychoses; in fact, only 1 stalker has been recognized totally mentally sick). However, it is the interaction of several psychopathological aspects that altogether determine a specific behaviour and that, analyzed as a whole and in relation to the crime, are so severe as to be referred to as insanity that reduces or excludes mental competence, as shown in $95 \%$ of the cases of our sample.

Regarding the victim of stalking: tormenting harassment in $45 \%$ of our samples were carried out to damage former-partners: this in line with what is widely reported in literature, that highlights that stalkers of former partners represent the widest sub-category of stalkers. Spitzberg (in his review of 40 studies) reports an average percentage of $49 \%$ of stalkers of former partners (Sheridan et al., 2003 by Spitzberg 2002).

In line with studies reported in literature, our survey highlights the close connection between the present and past sentimental or intimate relationship between victim and stalker and the onset of aggressive behaviours of the latter. In our sample, the most serious manifestations of violence have in fact been noted in the cases of stalking towards former partners with personal injury, stabbing, concussion, beatings, hetero aggression, throwing of stones, damaging personal objects and, in the most serious case, murder. The frequency of violent behaviours committed by the stalkers towards their victims is high, generally between 25 and $40 \%$ of cases (Marazziti 2015 from Meloy 2002) and in any case higher than that of other groups, such as for example psychiatric patients affected by Substance Abuse Disorder (Marazziti, 2015 from Steadman et al. 1998). Stalkers of intimate former partners are more likely to behave violently than stalkers of strangers or those seeking intimacy (Sheridan, 2003 et al. from Farham et al. 2000; Kienlen et al., 1997; Mullen et al., 1999; Pathè and Mullen, 1997). Five independent research groups based in three different continents have recently reported a frequency of violent behaviour varying from 55 to 89\% (Marazziti, 2015 from Meloy, 1998 and Harmon,1998). Regarding the relationship between victim and diagnosis of the stalker, Coleman (2000) states that stalkers of former partners are more likely to have a diagnosis of Substance Abuse and Antisocial and Narcissistic Personality Disorders. Farham et al. (2000) argue that stalkers of former partners are less likely to be psychotic than other stalkers. In our sample, stalkers with psychotic disorder (25\%) have harassed mostly unknown victims or acquaintances and used less damaging modes, such as cyberstalking, unwanted communications, shadowing. Conversely, the predominant diagnoses in those who stalk former partners are Substance Use Disorders, Mood (including Adaptation Disorders) and Personality Disorders (Sheridan et al., 2003 from Farham et al. 2000).
Blaauw and Winlkel (2002) noted that stalkers of former partners showed a greater diversity of stalking behaviours, and that such behaviours had an attrition rate faster than that of other subgroups (Sheridan et al., 2003 from Blaauw and Winlkel 2002). These data, as already hypothesized, could be explained referring to the "affection theory" and particular insecure affection types that would make the stalkers more reactive to relational breaks (Grattagliano, 2012). Sexual intimacy can accentuate abnormal affection reactions and increase emotional reactions when the relationship is wavering or interrupted (Marazziti, 2015). This originates stalking behaviours aimed at preventing the victim from ending the relationship in a definitive way. In these cases some authors define violence as "emotional" and characterized by intense excitement and anger, fear of an imminent refusal, which is experienced as a danger (Marazziti 2015 from Mullen et al., 2000 and Meloy 2003), and a threat of self-annihilation.

As in the most serious case examined in our sample, the idea of possession on the victim can result in murder. The risk of homicide in stalking is estimated at around $0.25 \%$ (Marazziti, 2015 from Meloy and Boyd 2003), although more recent data suggest that stalking may represent a significant predictor of marital homicide (Marazziti, 2015 from McFarlane et al. 2002).

Despite the many similarities between our results and those reported in literature, we could conclude that although most stalkers tend to have similar characteristics, there are anyhow anomalous behaviours, thus meaning that it is not possible to promptly identify authors of stalking (Sheridan et al., 2003). Due to the wide spread of the phenomenon, also confirmed by the data extracted in the Sardinian reality, and given the extreme risk of violence that is associated in particular with the stalkers of former partners, that may also lead to the victim's murder, even considering that there are some characteristics that allow us to draw a risk profile of the stalker and the predictive factors of future violence, it would be advisable to create facilities for stalking prevention, where to take care not only of the victim but, above all, of the potential offender and the molester-victim dyad. Such facilities should provide support to those couples who are experiencing the delicate phase of separation, being a point of reference where the potential harassing molester, if necessary, can receive psychotherapeutic, legal, psycho-educational and psychiatric support. In Sardinia, the Forensic Psychiatry Service of Cagliari, in agreement with the Court of Cagliari, is working on the guidelines that provide for the establishment of facilities that take care of the "stalker". Therefore, these should not be intended only for the victim of this crime, but also of the stalker in order to prevent recidivism of crime.

\section{References}

Alfarano E., La Tegola D., Carabellese F., Catanesi F., (2012), Stalking al femminile: una rewiew di letteratura, Rassegna Italiana di Criminologia, pag. 22.

Berti A., Fizzotti C., Maberino C., Zanelli E., (2005), Stalking, dalla clinica alla teoria: lo Stalker, Rivista di Psichiatria, 40, 3.

Buzzi F., Vanini M., (2014), da De Fazio L., Galeazzi G.M., Le vittime di stalking: in percorsi di aiuto per le vittime di stalking, Ed. Franco Angeli (2007), in Guida alla valutazione psichiatrica e medico legale del danno biologico di natura psichica, Giuffrè Editore.

Catanesi R., Carabellese F., La Tegola D., Alfarano E., (2013), Coexistence and Independence Between a Mental Disorder and Female Stalking, J Forensic Sci, January 2013, Vol. 58, No. 1 doi: 10.1111/j.1556-4029.2012.02210. 
Catanesi R., Carabellese F., La Tegola D., Alfarano E., (2013), from Dressing H, Kuehner C., Gass P., (2005) Prevalence of stalking in Germany. Psychiatr Prax; 32(2):73-8; in Coexistence and Independence Between a Mental Disorder and Female Stalking, J Forensic Sci, January 2013, Vol. 58, No. 1.

Coleman, F.L. (2000), Clinical characteristics of stalkers, Dissertation Abstracts International: Section B: The Sciences and Engineering, 60, 5766.

Galeazzi G.M., Curci P., (2001), The tormenting harasser syndrome (stalking): a review, Journal of Psychopathology, vol 7, 434-52.

Galeazzi G.M., Curci P., Secchi C., (2003) from Meloy (1999) Stalking: an Old Behavior, a New Crime, Psychiat. Clin. North Am., vol. 22, 85-99, in La sindrome delle molestie assillanti (stalking), Manuali di Psicologia, Psichiatria, Psicoterapia, Bollati Boringhieri.

Gargiullo B.C., Damiani R., (2010), Vittime di un amore criminale, la violenza in famiglia, natura, profili tipologici, casistica clinica e giudiziaria, Franco Angeli.

Grattagliano I. et al., (2012), Stalking un vecchio comportamento e un nuovo reato, riflessioni su undici casi accertati nel Distretto Giudiziario di Bari from Mullen P.E., Pathè M., Purcell R.R., Stalkers and their victims, p. 66; New York, NY: 47,1 Cambridge, 2000 in Rivista di psichiatria.

Kelly B.D., (2005), Erotomania: epidemiology and management. Cns Drugs2005; 19:657-69.

Kelly B.D., (2017), Love as delusion, delusions of love: erotomania, narcissism and shame, group.bmj.com, 10.1136/medhum-2017011198.

Kelly B.D., (2017), from Kennedy N., Kelly B.D., Shanley D., et al. (2000) A case of co-existent Capgras and de Clerambault's syndrome. J Psychol Med 17:69-71, in Love as delusion, delusions of love: erotomania, narcissism and shame, group.bmj.com, 10.1136/medhum-2017-011198.

Kelly B.D., (2017), from Kraepelin E., Robertson G.M., (1921) Manic depressive insanity and paranoia. Edinburgh: Livingstone, in Love as delusion, delusions of love: erotomania, narcissism and shame, group.bmj.com, 10.1136/medhum-2017011198.

Marazziti D., Falaschi V., Lombardi A., Mungai F., Dell'Osso L., (2015), Stalking: a neurobiological perspective, Riv Psichiatr 2015;50:12-18.

Marazziti D., Falaschi V., Lombardi A., Mungai F., Dell'Osso L., (2015), from Harmon R, R Rosner, Owens H. sesso e violenza in una popolazione forense di molestatori ossessivi, Psychol Public Policy legge del 1998; in Stalking: a neurobiological perspective, Riv Psichiatria.

Marazziti D., Falaschi V., Lombardi A., Mungai F., Dell'Osso L., (2015), from Meloy J.R. La psicologia di stalking: prospettive cliniche e forensi. San Diego, CA: Academic Press, (1998), in Stalking: a neurobiological perspective, Riv. Psichiatria.

Marazziti D., Falaschi V., Lombardi A., Mungai F., Dell'Osso L., (2015), from Meloy J.R., (2003), When stalkers become violent: the threat to public figures and private lives, Psychiatric Annals 33:659-65.

Marazziti D., Falaschi V., Lombardi A., Mungai F., Dell'Osso L., (2015), from McFarlane J.Campbell J., Watson K., Intimate partner stalking and feminicide: implicazioni urgenti per la sicurezza delle donne, Behav Legge Sci 2002; 20: 51-68, in Stalking: a neurobiological perspective, Riv Psichiatria.

Marazziti D., Falaschi V., Lombardi A., Mungai F., Dell'Osso L., (2015), from Steadman H., Mulvey E., Monahan J., et al., La violenza da parte di persone dimesse dalle strutture ospedaliere psichiatriche acute e da altri negli stessi quartieri, Arch Gen
Psychiatry 1998; 55: 393-401, in Stalking: a neurobiological perspective, Riv Psichiatria.

McEwan T.E. and Strand S., (2013), The role of psychopathology in stalking by adult strangers and acquaintances, Australian \& New Zealand Journal of Psychiatry 47(6) 546-555.

McEwan T.E. and Strand S., (2013), from Abrams K. M. and Robinson G. E. (2011) Stalking by patients: doctors' experiences in a Canadian urban area. Journal of Nervous and Mental Disease 199:738-743; and from Morgan R.K. and Kavanaugh K.D. (2011) Student stalking of faculty: Results of a nationwide survey, College Student Journal 45:512-523; and from Purcell R., Powell M.B. and Mullen P.E. (2005) Clients who stalk psychologists: prevalence, methods, and motives. Professional Psychology: Research and Practice 36: 537-543, in The role of psychopathology in stalking by adult strangers and acquaintances, Australian \& New Zealand Journal of Psychiatry 47(6) 546-555.

McEwan T.E. and Strand S., (2013), from James D.V., Mullen P., Pathé M., et al. (2009) Stalkers and harassers of royalty: The role of mental illness and motivation. Psychological Medicine 39: 1479-1490; in The role of psychopathology in stalking by adult strangers and acquaintances, Australian \& New Zealand Journal of Psychiatry 47(6) 546-555.

McEwan T.E. e Strand S., (2013) from Mohandie K., Meloy J.R., McGowan M.G., et al. (2006) The RECON typology of stalking: Reliability and validity based on a large sample of North American stalkers. Journal of Forensic Sciences 51: 147-155.

McEwan T.E. and Strand S., (2013), from Morrison K.A. (2008), Differentiating between physically violent and nonviolent stalkers: An examination of Canadian cases, Journal of Forensic Sciences 53: 742-751, in The role of psychopathology in stalking by adult strangers and acquaintances, Australian \& New Zealand Journal of Psychiatry 47(6) 546-555.

McEwan T.E. and Strand S., (2013), from Rosenfeld Band Harmon R. (2002) Factors associated with violence in stalking and obsessional harassment cases, Criminal Justice and Behavior 29: 671-691 in The role of psychopathology in stalking by adult strangers and acquaintances, Australian \& New Zealand Journal of Psychiatry 47(6) 546-555.

McEwan T.E. and Strand S., (2013) from Whyte S, Petch E., Penny C., et al. (2008), Who stalks? A description of patients at a high security hospital with a history of stalking behaviour, Criminal Behaviour and Mental Health 18: 27-38, in The role of psychopathology in stalking by adult strangers and acquaintances, Australian \& New Zealand Journal of Psychiatry 47(6) 546-555.

McIvor R.J., Potter L., Davies L., (2008) Stalking behaviour by patients towards psychiatrists in a large mental health organization, Int J Soc Psychiatry; 54(4): 350-7, in Ostermeyer et al. 2016 pag. 270; McEwan T.E. and Strand S. 2013.

Meloy J.R., (1997), The clinical risk management of stalking. Am J. Psychother, 51:174-84.

Meloy J.R. (1999) Stalking: an Old Behavior, a New Crime, Psychiat. Clin. North Am., vol. 22, 85-99.

Meloy J.R., (2007), Stalking: The state of the science [Editorial], Criminal Behaviour and Mental Health 17: 1-7, in McEwan T.E. and Strand S., 2013 and by Marazziti, 2015.

Meloy J.R., Boyd C., (2003), "Female stalkers and their victims", Journal of the American Academy of Law and Psychiatry, 31(2), 211-219.

Mullen P.E., Pathè M., Purcell R., et al., (1999), A study of stalkers, AM j. Psychiatry;156:1244-9, in McEwan T.E. and Strand S., (2013) and in Sheridan (2003) et al.

Mullen P.E., Pathè M., Purcell R., (2000), Stalkers and their victims. 
New York, NY: Cambridge, in Sheridan, L.P., Blaauw E., Davies G., (2003); also in Marazziti D. 2015.

Ostermeyer B. et al., (2016), Stalking and Violence, Psychiatr Clin North Am. 39(4): 663-673.

Ostermeyer B. et al., (2016), from Friedman S.H. (2015), Realistic consideration of women and violence is critical, J Am Acad Psychiatry; in Stalking and Violence. Psychiatr Clin North Am. 39(4): 665-666.

Ostermeyer B. et al., (2016), from McCann J.T., et al., (2000), A descriptive study of child and adolescent obsessional followers, J Forensic Sci 45(1):195-9, in Stalking and Violence. Psychiatr Clin North Am. 39(4): 666-667.

Ostermeyer B. et al., (2016), from West S.G. et al., (2008), These boots are made for stalking: characteristics of female stalkers, Psychiatry, Edgmont; and from Meloy J.R., Stalking in Siegel J.A, et al. Editors Encyclopedia of Forensic Sciences (2013) in Stalking and Violence, Psychiatr Clin North Am.

Pathè M., et al. (2002), Surviving stalking, Cambridge, UK: Cambridge University, Press.

Pomilla A., D’Argenio A., Mastronardi V., (2012), Stalking: considerazioni clinico-criminologiche tramite i risultati di un contributo di ricerca, Supplemento alla Rivista di psichiatria, 47,4.

Purcell R., Moller B., Flower T., Mullen P.E., (2009), Stalking among juveniles, The British Journal of Psychiatry, 194, 451455 in Ostermeyer B. et al. 2016.

Rosenfeld B., (2003), Recidivism in stalking and obsessional harassment. Law and Human Behavior 27: 251-265.

Sansone R.A. and Sansone L.A., (2010), Fatal attraction syndrome: Stalking behavior and borderline personality. Psychiatry 7: 4246, in McEwan T.E. and Strand S., (2013).

Sheridan, L.P., Blaauw E., Davies G., (2003), from Blaauw, E. et al. (2002), Stopping stalking, Manuscript submitted for publication, in Stalking: Knowns and Unknowns, Trauma, Violence, \& Abuse, Vol. 4, No. 2, April 2003 148-162.

Correspondence: Francesca Manunza.

E-mail: manunzaf@gmail.com

Key words: Stalking and psychopathology; tormenting harassment; female stalking.

Parole chiave: Stalking e psicopatologia, molestie assillanti, stalking femminile.

Palabras clave: Acoso y psicopatología; molestias invasivas; acoso femenino.

Received for publication: 19 December 2016.

Revision received: 26 June 2017

Accepted for publication: 4 April 2018

Conference presentation: Part of this article was presented to the " $1^{\circ}$ Congresso Nazionale dell'Accademia Italiana di Criminologia, Sistema Penale, Investigazioni e Sicurezza" 27-29 April 2018, Rome Italy.

This article is distributed under the terms of the Creative Commons Attribution Noncommercial License (by-nc 4.0) which permits any noncommercial use, distribution, and reproduction in any medium, provided the original author(s) and source are credited.

(C) Copyright F. Manunza and G. Pintor, 2018

Licensee PAGEPress, Italy

Rivista di Psicopatologia Forense, Medicina Legale, Criminologia 2018; $23: 25$

doi:10.4081/psyco.2018.25
Sheridan L., Blaauw E., Davies G., (2003), from Farnham, James e Cantrell (2000), Association between violence, psychosis, and relationship to the victim in stalkers. Lancet; 355:19.

Sheridan L., Blaauw E., Davies G., (2003), from Coleman (2000), Clinical characteristics of stalkers, Dissertation Abstracts International: Section B: The Sciences and Engineering, 60, 5766.

Sheridan L.P., Blaauw E., Davies G., (2003), from Kordvani, A.H. (2000). Women stalking in Iran. Paper presented (by proxy) to the Criminal Justice Responses to Stalking Conference, Australian Institute of Criminology, Sydney, Australia in Stalking: Knowns and Unknowns, Trauma, Violence, \& Abuse, Vol. 4, No. 2, April 2003 148-162.

Sheridan L.P., Blaauw E., Davies G., (2003), from Mullen P.E., Pathè M, Purcell R, et al. (1999) A study of stalkers, AM j. Psychiatry, 156:1244-9; in Stalking: Knowns and Unknowns, Trauma, Violence, \& Abuse, Vol. 4, No. 2, April 2003 148-162. Sheridan L.P., Blaauw E., Davies G., (2003), from Meloy, J.R. (1997). A clinical investigation of the obsessional follower: "she loves me, she loves me not”, In L. Schlesinger (Ed.), Explorations in criminal psychopathology (pages. 9-32). Springfield, IL: Charles C Thomas; in Stalking: Knowns and Unknowns, Trauma, Violence, \& Abuse, Vol. 4, No. 2, April 2003 148-162.

Sheridan L.P., Blaauw E., Davies G., (2003), from Meloy, J.R. (1999). Stalking: An old behavior, new crime, Psychiatric Clinics of North America, 22, 85-99, in Stalking: Knowns and Unknowns, Trauma, Violence, \& Abuse, Vol. 4, No. 2, April 2003 148-162.

Sheridan L.P., Blaauw E., Davies G., (2003), from Spitzberg B. H., (2002), The tactical topography of stalking victimization and management. Trauma, Violence \& Abuse, 3, 261-2 in Stalking: Knowns and Unknowns, Trauma, Violence, \& Abuse, Vol. 4, No. 2, 2003 148-162.

Strand S, McEwan T.E., (2011), Same gender stalking in Sweden and Australia. Behav Sci Law; 29: 202-19.

West S.G., Friedman S.H., (2008). These boots are made for stalking: characteristics of female stalkers. Psychiatry (Edgmont) 5(8):37-42. 